\title{
New aspects of the formation of 2-substituted thiazolidine-4-carboxylic acids and their thiohydantoin derivatives
}

\author{
Ahmed R. E. Mahdy, Elghareeb E. Elboray, Ragab F. Fandy, \\ Hussien H. Abbas-Temirek, and Moustafa F. Aly* \\ Department of Chemistry, Faculty of Science, South Valley University, Qena 83523, Egypt \\ E-mail: mosfaly51@yahoo.com
}

DOI: https://doi.org/10.24820/ark.5550190.p009.861

\begin{abstract}
Aromatic aldehydes reacted readily with $(R)$-cysteine in boiling acidified methanol to give diastereomeric mixtures of the corresponding 2-(aryl substituted) thiazolidine-4-carboxylic acids. 4-Nitrobenzaldehyde under similar conditions afforded one isomer of 2-(4-nitrophenyl)thiazolidine-4-carboxylic acid, which epimerized in the NMR solvents into a diastereomeric mixture. 2-Nitrobenzaldehyde reacted with $(R)$-cysteine to afford 3,5-bis-(2-nitrophenyl)tetrahydro-1H-thiazolo[3,4-c]oxazol-1-one as the sole product, which collapsed in the NMR solvent into a diastereomeric mixture of the thiazolidine-4-carboxylic acids. The thiazolidine derivatives reacted smoothly with phenyl isothiocyanate to give single isomers of the corresponding thiohydantoins.
\end{abstract}

Keywords: Thiazolidine-4-carboxylic acids, thiohydantoins, cyclization, epimerization

\section{Introduction}

Penicillins are the class of antibiotic drugs contain a $\beta$-lactam nucleus fused to thiazolidine-4carboxylic acid derivatives (TCDs). ${ }^{1}$ The thiazolidine-4-carboxylic acid core used in biology as a pseudo-/thio-proline or bioisostere of proline to improve the desired biological or physical properties of a compound without making significant changes in the chemical structure. ${ }^{2-7}$ TCDs exhibit a broad spectrum of anticancer activities ${ }^{8-12}$ against, e.g. liver, ${ }^{13,14}$ breast, ${ }^{13-15}$ colon, ${ }^{13,16}$ prostate, ${ }^{17}$ endometrial ${ }^{13}$ and melanoma ${ }^{17}$ cell lines. In the same vein, TCDs are used as, e.g. antimalarial, ${ }^{18,19}$ selective $\mathrm{Na}^{+} / \mathrm{Ca}^{2+}$ exchange inhibitors, ${ }^{20}$ immunostimulating agents, ${ }^{21}$ tyrosinase inhibitors, ${ }^{22}$ influenza A neuraminidase inhibitors, ${ }^{23}$ antitubercular, ${ }^{24} \mathrm{HIV}-1$ protease inhibitors ${ }^{2,25}$ and ACE inhibitors. ${ }^{26}$ Furthermore, TCDs were introduced as versatile scaffolds in the syntheses of natural products, i.e. (+)-biotin, ${ }^{27,28}(+)$-lyngbyabellin $\mathrm{M},{ }^{29}(+)$-hyalodendrin, ${ }^{30}$ prepiscibactin ${ }^{31}$ and dehydroluciferin. ${ }^{32}$ Glutathione is a tripeptide works as a cellular protective agent and cannot 
be used as a drug because it does not enter the living cells. ${ }^{33}$ The vital amino acid building block in the in vivo synthesis of glutathione is $(R)$-cysteine, which cannot be supplemented directly due to toxicity and instability problems. ${ }^{33,34}$ TCDs work as $(R)$-cysteine prodrugs ${ }^{33,35}$ which metabolize intracellularly to release $(R)$-cysteine to stimulate glutathione synthesis. Straightforward formation of TCDs opens the door for this process to be used for detection of cysteine amino acid and $\mathrm{N}$ terminal cysteines ${ }^{36}$ and also for estimation/binding of aldehydes. ${ }^{37}$

The aim of this work is to use acidified methanol as a solvent in the preparation of some TCDs and to shed some light on the mechanism of their formation, and their conversion into the corresponding diastereospecific thiohydantoins.

\section{Results and Discussion}

The reaction of $(R)$-cysteine (1), salicylaldehyde (2a) and $N$-phenylmaleimide (3) (NPM, a reactive dipolarophile) in acidified methanol under reflux failed to give the expected cycloadduct $\mathbf{6}^{38}$ and instead gave a $98 \%$ yield of the well known (2RS)-(2-hydroxyphenyl)thiazolidine-( $\left.4 R\right)$ carboxylic acids (7a) and $(\mathbf{8 a})$ in a 1.5:1 ratio, respectively. It is worth mentioning that using acidified methanol gave a better yield and an opposite diastereomeric ratio compared to the previously reported results ${ }^{39}$ (Table, entry a). This result encouraged us to study the diastereoselectivity in the formation of 2-(substituted)thiazolidine-4-carboxylic acids by using our conditions.

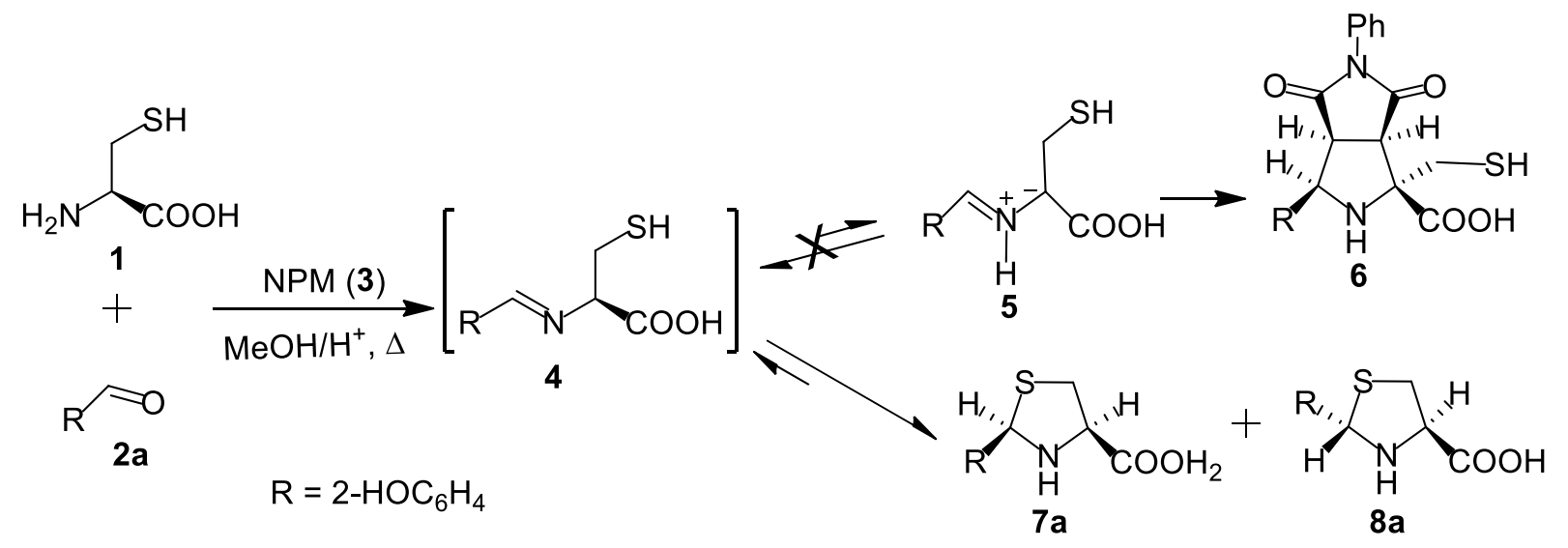

Scheme 1. The competition between cycloaddition and cyclization.

It seems that the Schiff's base 4 undergoes cyclization in such case much faster than the generation of azomethine ylide $\mathbf{5}$ and this could be mainly attributed to the bigger size and softer nature of the sulfur atom. The reaction starts by the formation of imine 4 which suffers an intramolecular nucleophilic attack by the thiol group from either side to furnish a diastereomeric mixture of 2-(substituted)thiazolidine-4-carboxylic acids. ${ }^{40,41}$ The isomerization at C-4 of the thiazolidine via deprotonation/protonation is ruled out based on spectroscopic data (vide infra). It 
is believed that, under our conditions, the generation of azomethine ylide has not been formed and hence the chirality at C-4 remained unchanged. Heating under reflux a mixture of $(R)$-cysteine (1) and formaldehyde (2b) in acidified aqueous methanol $\left(\mathrm{MeOH} / \mathrm{H}_{2} \mathrm{O} / \mathrm{AcOH} 1: 1\right.$ : drops) gave an $84 \%$ yield of thiazolidine-( $4 R$ )-carboxylic acid (7b) (Entry b).

Table. Formation of 2-(substituted)thiazolidine-4-carboxylic acids

\begin{tabular}{cccc} 
& & & \\
Entry & $\mathrm{R}$ & $\mathrm{Yield}(\mathrm{Lit})$. & $\mathrm{Ratio} 7: \mathbf{8}^{i}(\mathrm{Lit} .)^{i i}$ \\
\hline $\mathrm{a}$ & $2-\mathrm{HOC}_{6} \mathrm{H}_{4}$ & $98^{38}(78)^{39}$ & $1.5: 1^{38}(1: 2.3)^{39}$ \\
$\mathrm{~b}$ & $\mathrm{H}$ & $84\left(82,{ }^{39} 98^{42}\right)$ & - \\
$\mathrm{c}$ & $\mathrm{Ph}$ & $88\left(89,{ }^{43} 71^{42}\right)$ & $2: 1\left(2.3: 1,{ }^{43} 1: 1.2^{42}\right)$ \\
$\mathrm{d}$ & $4-\mathrm{HOC}_{6} \mathrm{H}_{4}$ & $89\left(86,{ }^{42} 91^{39}\right)$ & $3: 1\left(1: 1.1,{ }^{42} 1: 1.9^{39}\right)$ \\
$\mathrm{e}$ & $2-\mathrm{MeOC}_{6} \mathrm{H}_{4}$ & $75\left(65,{ }^{43} 83^{39}\right)$ & $2: 1\left(1: 1.5,{ }^{43} 1: 2.7^{39}\right)$ \\
$\mathrm{f}$ & $4-\mathrm{ClC}_{6} \mathrm{H}_{4}$ & $93\left(75,{ }^{43} 73^{39}\right)$ & $1.4: 1\left(19: 1,{ }^{43} 1: 1.9^{39}\right)$ \\
$\mathrm{g}$ & $3-\mathrm{NO}_{2} \mathrm{C}_{6} \mathrm{H}_{4}$ & $92\left(80^{39}\right)$ & $2: 1\left(1: 1^{39}\right)$ \\
$\mathrm{h}$ & $4-\mathrm{NO}_{2} \mathrm{C}_{6} \mathrm{H}_{4}$ & $89\left(90,{ }^{42} 80^{43}\right)$ & $100: 0^{i i i}\left(1.9: 1,,^{42} 1: 19^{43}\right)$ \\
\hline
\end{tabular}

${ }^{1} \mathrm{H}-\mathrm{NMR}$ spectra were recorded in: (i) $\mathrm{CDCl}_{3} / \mathrm{TFA}$, (ii) DMSO-d $d_{6}$, (iii) $\mathrm{CDCl}_{3} / \mathrm{CD}_{3} \mathrm{OD}$

Furthermore, refluxing an equimolar mixture of $(R)$-cysteine $(\mathbf{1})$ and benzaldehyde $(\mathbf{2 c})$ as the carbonyl component in acidified methanol gave an $88 \%$ yield of 2-phenylthiazolidine-4-carboxylic acid (7c) and (8c) as an isomeric mixture in a 2:1 ratio, respectively (Entry c). The pure configuration of both diastereomers $7 \mathbf{c}$ and $\mathbf{8 c}$ was assigned on the basis of the experimental NOE data which supported the relationship between the substituents at C-2 and C-4 to be cis-7c and trans-8c. Thus, in the case of 7c, irradiation of 2-H gave 3.8 and $3.7 \%$ enhancement for $4-\mathrm{H}$ and 5-Ha protons, respectively. Also, irradiation of 4-H showed 3.1 and $1.4 \%$ enhancement of $2-\mathrm{H}$ and 5-Ha protons, respectively. However, in the case of $\mathbf{8 c}$, irradiation of 2-H and 4-H protons gave no effect across the ring.

Aryl aldehydes $\mathbf{2 d - g}$ reacted with $(R)$-cysteine $(\mathbf{1})$ under the same conditions to produce diastereomeric mixtures of 2-substituted thiazolidine-4-carboxylic acids 7d-g and 8d-g in 75-93\% yield (Entries d-g). It is worth noting that the diastereomeric ratio depends on the NMR solvent. Thus, the ${ }^{1} \mathrm{H}-\mathrm{NMR}$ spectrum of the isomeric mixture $\mathbf{7 f}$ and $\mathbf{8 f}$ in $\mathrm{CDCl}_{3} / \mathrm{CD}_{3} \mathrm{OD}$ showed a $2.5: 1$ ratio, respectively, whereas in $\mathrm{CDCl}_{3} / \mathrm{TFA}$, the isomeric ratio of $\mathbf{7 f}$ and $\mathbf{8 f}$ was 1.4:1, respectively. This result also confirmed that the epimerization process at $\mathrm{C}-2$ is solvent and $\mathrm{pH}$ dependent. ${ }^{44,45}$ The recorded NOE data of $\mathbf{7 f}$ and $\mathbf{8 f}$, yet again, supported the cis-relationship in the case of the major isomer $\mathbf{7 f}$ and trans-relationship of the minor isomer $\mathbf{8 f}$ (see experimental). 
Surprisingly, the use of 4-nitrobenzaldehyde (2h) as the carbonyl component lead to the formation of 2-(4-nitrophenyl)thiazolidine-4-carboxylic acid (7h) as the only product in an $89 \%$ yield (Entry h). The stereochemistry of $\mathbf{7 h}$ was established on the basis of its spectral data (see experimental and chart 1a). Standing compound $\mathbf{7 h}$ in the NMR solvent $\left(\mathrm{CDCl}_{3} / \mathrm{CD}_{3} \mathrm{OD}\right)$ for $20 \mathrm{~min}, 7 \mathrm{~h}$ and $24 \mathrm{~h}$ at room temperature gave an isomeric mixture of $\mathbf{7 h}$ and $\mathbf{8 h}$ in 21:1, 3:1 and 1.4:1 ratios, respectively (Chart $1 \mathrm{~b}-1 \mathrm{~d}$ ). Extending the time for $48 \mathrm{~h}$ (Chart 1e) under the same conditions afforded a 1:1 ratio and no further change was noticed even after one week. It is believed that the obtained isomer $\mathbf{7 h}$ in solution would be in equilibrium with Schiff's base $\mathbf{4 h}$, which suffers a nucleophilic attack by the thiol group from the opposite side to give the other cyclization product $\mathbf{8 h}$ (Scheme 2). Repeating the ${ }^{1} \mathrm{H}-\mathrm{NMR}$ experiment for compound $\mathbf{7 h}$ in a different solvent $\left(\mathrm{CDCl}_{3} / \mathrm{TFA}\right)$ showed immediately an isomeric mixture of $\mathbf{7 h}$ and $\mathbf{8 h}$ in a 2:1 ratio, respectively. It is obvious that the presence of TFA accelerates the epimerization rate, and the unshared pair of electrons on the thiazolidine nitrogen drives the epimerization process.

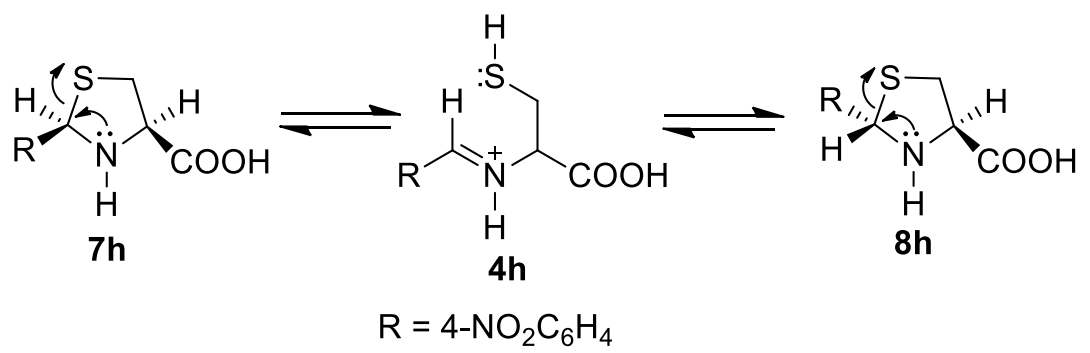

Scheme 2. Epimerization of $\mathbf{7 h}$ into $\mathbf{8 h}$ via ring opening and recyclization.

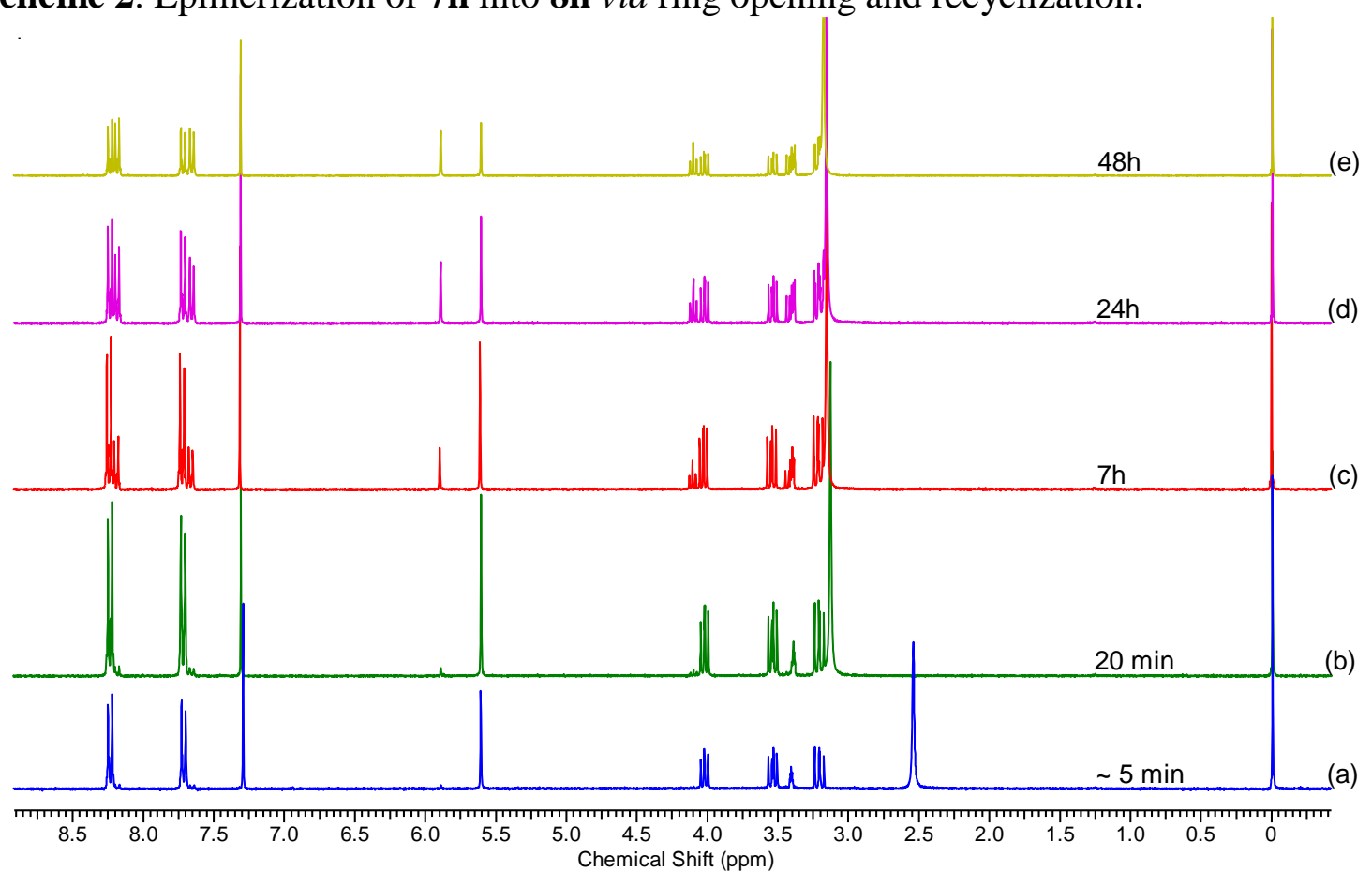

Chart 1. ${ }^{1} \mathrm{H}-\mathrm{NMR}\left(\mathrm{CDCl}_{3} / \mathrm{CD}_{3} \mathrm{OD}\right)$ experiments illustrating the epimerization of $\mathbf{7 h}$. 
On the other hand, $(R)$-cysteine (1) reacted with 2-nitrobenzaldehyde (2i) as the carbonyl component under the same conditions to give a $46 \%$ yield of 3,5-bis(2-nitrophenyl)tetrahydro- $1 \mathrm{H}$ thiazolo[3,4-c] oxazol-1-one (9) as the sole product (Scheme 3). The obtained bicyclic compound is attributed to the high reactivity of the aldehyde and the steric congestion, which facilitate the formation of the second oxazolone ring.

The stereochemistry of 9 was established on the basis of its spectral data (see experimental and Chart 2a). The ${ }^{1} \mathrm{H}-\mathrm{NMR}\left(\mathrm{CDCl}_{3} / \mathrm{CD}_{3} \mathrm{OD}\right)$ sample of 9 was left at room temperature for $48 \mathrm{~h}$, after which time traces of the trans-thiazolidine-4-carboxylic acid derivative $8 \mathbf{i}$ was observed together with 2-nitrobenzaldehyde in 8:1:1 ratio, respectively (Chart 2b). The ${ }^{1} \mathrm{H}-\mathrm{NMR}$ studies of the obtained compound 9 in a different solvent ( $\left.\mathrm{CDCl}_{3} / \mathrm{TFA}\right)$ lead to a diastereomeric mixture of 2(2-nitrophenyl)thiazolidine-4-carboxylic acids (7i) and (8i) in a 1:1 ratio (Scheme 4). Accordingly, 2-nitrobenzaldehyde was observed and supported the suggested mechanism in scheme 4.

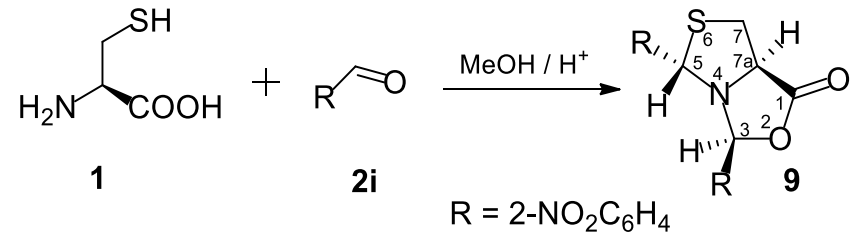

Scheme 3. Synthesis of 3,5-bis(2-nitrophenyl)tetrahydro-1H-thiazolo[3,4-c] oxazol-1-one 9.

Going through the literature revealed that the diastereomeric ratio depends on (i) the conditions at which the reaction was conducted, and (ii) the ${ }^{1} \mathrm{H}-\mathrm{NMR}$ solvent used. ${ }^{39-43}$ It seems that using our optimal conditions in the synthesis of 2-(substituted)thiazolidine-4-carboxylic acids affects both the experimental yield and diastereomeric ratio (Table). Thus, using such conditions afforded diastereomeric mixtures of $\mathbf{7}$ and $\mathbf{8}$ in 75-98\% yields, and the cis-diastereomer $\mathbf{7}$ was obtained as the major product in all cases. Interestingly, the cis-diastereomer $\mathbf{7 h}$ was obtained as the sole product, and it was also lucky for us to separate thiazolo[3,4-c] oxazol-1-one 9 as the only product with no trace of the thiazolidine derivatives.

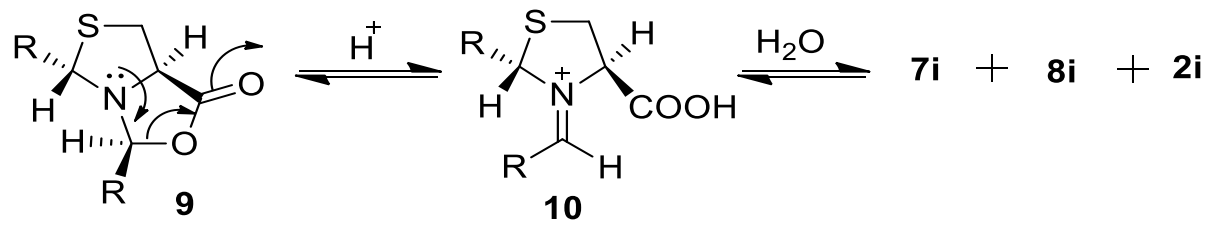

Scheme 4. Collapse of 9 into thiazolidine-4-carboxylic acids $\mathbf{7 i}$ and $\mathbf{8 i}$.

Thiohydantoins are common skeletons in organic synthesis and have a broad spectrum of biological applications. ${ }^{46,47}$ Annulation of hydantoin ring to thiazolidine derivatives showed anticancer activity (modulator of P53 activity) ${ }^{11}$ and assumed to treat Alzheimer via interaction 
with amyloid $\beta$ peptide (A $\beta$ 25-35). ${ }^{48}$ It seemed to us that annulation of thiohydantoin moiety to thiazolidines might have biological applications.

Lalezari $^{49}$ and Balalaie ${ }^{50}$ have reported two different methods for obtaining 6-phenyl-5thioxotetrahydroimidazo[1,5-c] thiazol-7-one (12b) in 86 and 97\% yields, respectively. However, the same product was formed in $95 \%$ yield by using our simple and convenient procedure. Thus, stirring an equimolar mixture of thiazolidine-4-carboxylic acid (7b) and phenyl isothiocyanate (11) in acidified methanol at room temperature gave $\mathbf{1 2 b}$ (Scheme 5). The stereochemistry of $\mathbf{1 2 b}$ was assigned according to its spectral data and by comparison with the previously reported data. ${ }^{50}$

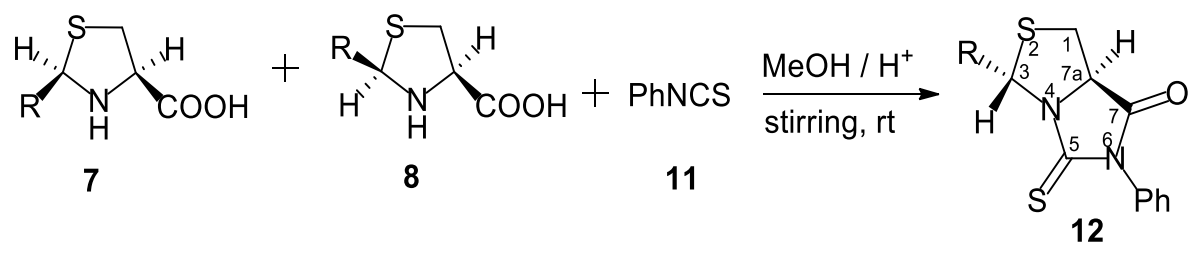

(b) $\mathrm{R}=\mathrm{H},(\mathbf{c}) \mathrm{R}=\mathrm{Ph}$, (d) $4-\mathrm{HOC}_{6} \mathrm{H}_{4}$, (e) $4-\mathrm{OMeC}_{6} \mathrm{H}_{4}$, (f) $4-\mathrm{ClC}_{6} \mathrm{H}_{4}$, (g) $\mathrm{R}=3-\mathrm{NO}_{2} \mathrm{C}_{6} \mathrm{H}_{4}$, (h) $\mathrm{R}=4-\mathrm{NO}_{2} \mathrm{C}_{6} \mathrm{H}_{4}$

Scheme 5. Formation of thiohydantoins 12.

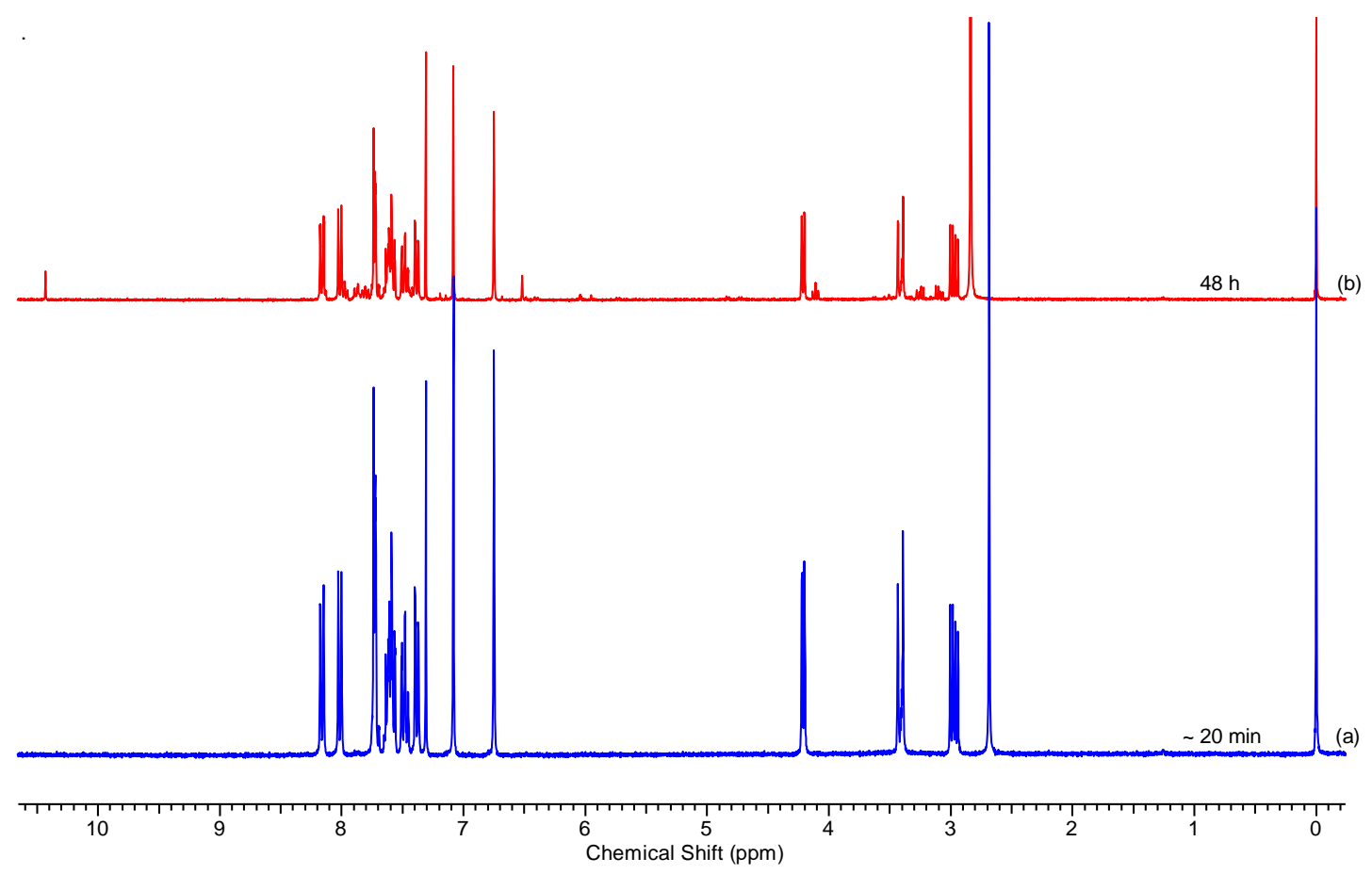

Chart 2. ${ }^{1} \mathrm{H}-\mathrm{NMR}$ spectra $\left(\mathrm{CDCl}_{3} / \mathrm{CD}_{3} \mathrm{OD}\right)$ of 9.

Similarly, the reaction of an isomeric mixture of $\mathbf{7 c}$ and $\mathbf{8 c}(\mathrm{R}=\mathrm{Ph})$ with $\mathbf{1 1}$ gave 3,6-diphenyl5-thioxo-tetrahydro-imidazo[1,5-c]thiazol-7-one 12c as the only product in a $97 \%$ yield. However, the diastereomeric mixtures of $\mathbf{7 d - h}$ and $\mathbf{8 d - h}$ reacted in the same manner with $\mathbf{1 1}$ to afford 
thiohydantoins 12d-h as the only products in excellent yields (91-99\%). The stereochemistry of these thiohydantoins 12 was confirmed based on the NOE data of 12c,f (see experimental). Thiohydantoins $\mathbf{1 2}$ are stable and no sign of isomerization at C-3 was observed and this could be mainly attributed to the presence of thioxo-group adjacent to N-4. Our results comply with the literature work, which showed that the $\mathrm{N}$-protection of thiazolidine-4-carboxylic acid prevented the epimerization at $\mathrm{C}-2 .{ }^{36}$

The possible mechanism for thiohydantoins 12 started through the preferential attack of the thiazolidine nitrogen of 7 on phenyl isothiocyanate (11) from the opposite face to give the favourable thiourea derivatives $\mathbf{1 3}\left(\mathrm{K}_{1}>>\mathrm{K}_{2}\right)$ (Scheme 6). ${ }^{40,51}$ However, such conformation of $\mathbf{1 3}$ prevents the formation of cis-thiohydantoins 14 and alternatively, the intermediate 15 would consequently lead to the trans-thiohydantoins $\mathbf{1 2}$.

Györgydeák et al., ${ }^{52}$ reported a different mechanism for the synthesis of thiohydantoin-fused thiazolidines, assuming a break-down of C-2-N-3 bond in the thiourea intermediate to produce a ring open intermediate with a positively charged sulfur in order to change the stereochemistry at $\mathrm{C}-2$. However, the same authors have refused a similar mechanism suggested by referees during their early work on $\mathrm{N}$-acetylthiazolidines. ${ }^{41}$ We believe that our proposed mechanism (vide supra) would serve well to rationalise the stereochemistry at C-3 in the obtained thiohydantoins.

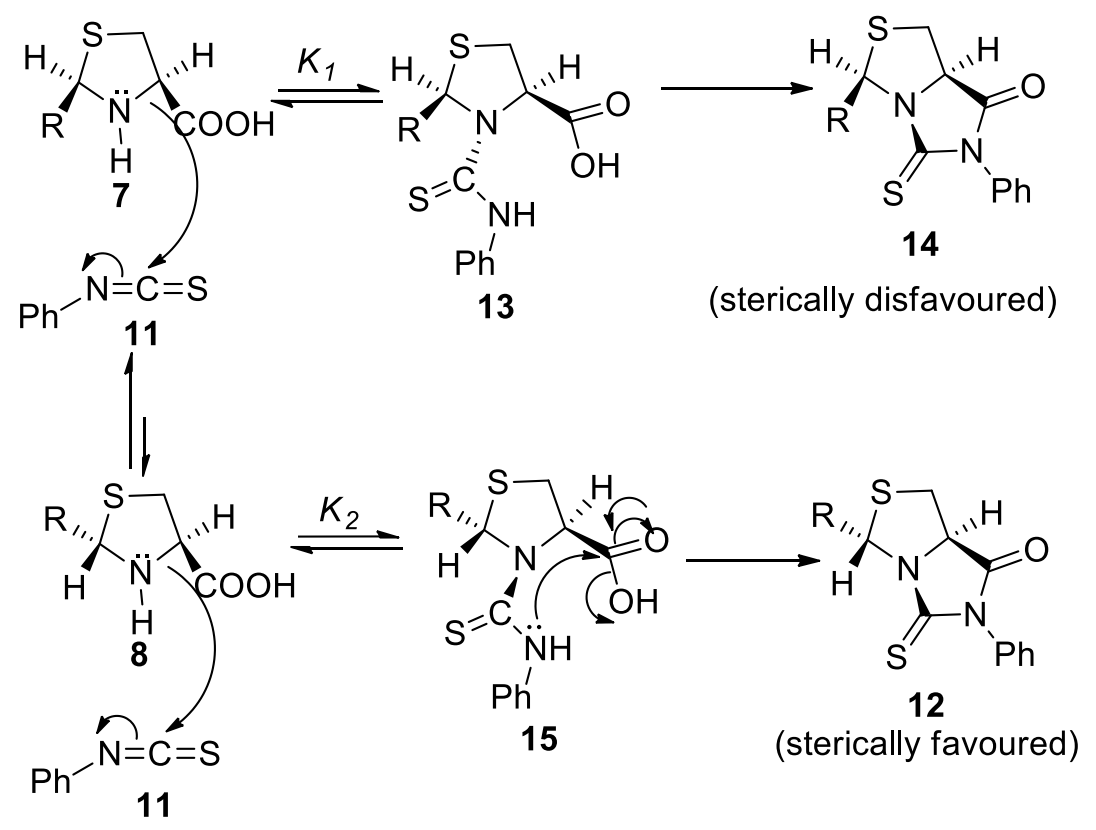

Scheme 6. Plausible mechanism for thiohydantoins 12.

Interestingly, reacting 3,5-bis-(2-nitrophenyl)dihydro-hiazolo[3,4-c]oxazolidine-1-one (9) with phenyl isothiocyanate (11) under the same conditions gave a 95\% yield of 3-(2-nitrophenyl)6-phenyl-5-thioxo-tetrahydro-imidazo[1,2-c]thiazol-7-one (12i) as the only product according to the suggested mechanism (Scheme 7). In the ${ }^{1} \mathrm{H}-\mathrm{NMR}$ spectra of thiohydantoins 12, H-3 appeared 
deshielded and this could be attributed to the presence of thioxo-group on N-4 and the almost perpendicular dihedral angel relationship ${ }^{49}$ between the thiazolidine ring and the C-3 aryl substituent. This arrangement positioned the H-3 proton in the deshielding area of the aryl group at C-3.

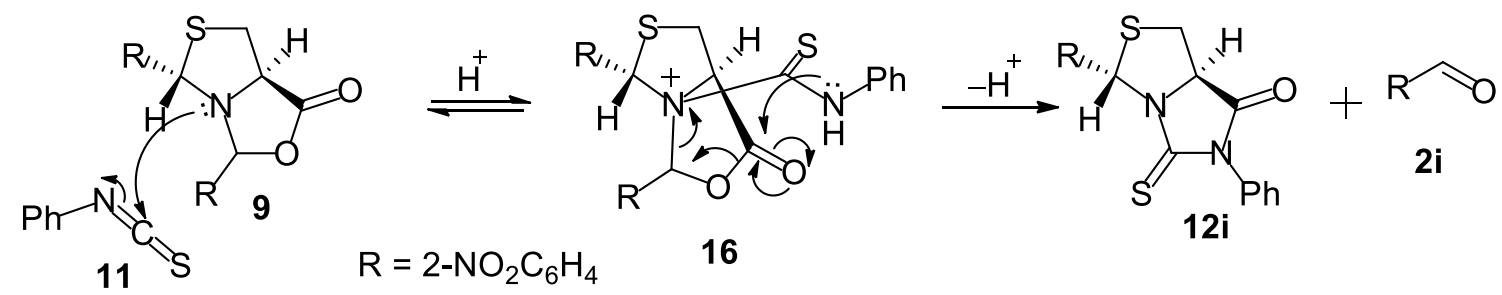

Scheme 7. Possible mechanism for thiohydantoin 12i.

\section{Conclusions}

2-Substituted thiazolidine-4-carboxylic acids were easily obtained as nonseparable diastereomeric mixtures via the reaction of aldehydes with $(R)$-cysteine in acidified methanol. 4-Nitrobenzaldehyde gave only one isomer which epimerized gradually in the NMR solvent $\left(\mathrm{CDCl}_{3} / \mathrm{CD}_{3} \mathrm{OD}\right)$ to a mixture of diastereomers. 2-Nitrobenzaldehyde reacted with $(R)$-cysteine to afford 3,5-bis(2-nitrophenyl)tetrahydro-1H-thiazolo[3,4-c]oxazol-1-one (9) as an exclusive product which collapsed in the NMR solvents to a diastereomeric mixture of thiazolidines $7 \mathbf{i}$ and 8i. The equilibrium between the two diastereomers is time and $\mathrm{pH}$ dependent. The obtained thiazolidine derivatives reacted smoothly with phenyl isothiocyanate to afford the corresponding thiohydantoins.

\section{Experimental Section}

\section{General technical data}

Thin layer chromatography (TLC) was carried out on aluminium plates pre-coated with silica gel 60 F254 (Merck), and were visualised using ultraviolet light and/or aqueous $\mathrm{KMnO}_{4} / \mathrm{I}_{2}$. Proton nuclear magnetic resonance spectra were recorded at $300 \mathrm{MHz}$ on Bruker DPX300 and Oxford NMR instruments. Chemical shifts $(\delta)$ are reported in parts per million relative to tetramethylsilane $(\delta=0.00)$ and coupling constants are given in hertz $(\mathrm{Hz})$. The following abbreviations are used: $\mathrm{s}$ $=$ singlet, $\mathrm{d}=$ doublet, $\mathrm{br}=$ broad, $\mathrm{dd}=$ doublet of doublets, $\mathrm{dt}=$ doublet of triplets, $\mathrm{m}=$ multiplet, $\mathrm{t}=$ triplet, $\mathrm{td}=$ triplet of doublets. ${ }^{13} \mathrm{C}-\mathrm{NMR}$ spectra were recorded at $75 \mathrm{MHz}$ on a Bruker DPX300 instrument and chemical shifts are reported in parts per million (ppm). ${ }^{1} \mathrm{H}-\mathrm{NMR}$ peak assignments are mainly based on DEPT135, COSY, HMQC and HMBC spectral data. Accurate masses were obtained using a Bruker Daltonics micrOTOF spectrometer. Mass spectra were recorded at 70ev 
using Shimadzu GCMS-QP1000EX mass spectrometer. The IR spectra were measured on Shimadzu IR instrument. Melting points (m.p.) were determined on a Kofler hot-stage apparatus and are uncorrected. All compounds are named according to the IUPAC system using the ChemBioDraw Ultra 12.0 program.

Method (A): Synthesis of 2-substituted thiazolidine-4-carboxylic acids

Stirring with heating under reflux an equimolar mixture $(0.01 \mathrm{~mol})$ of the carbonyl component 2 and (R)-cysteine 1 in acidified methanol (10:0.1 v/v $\mathrm{MeOH} / \mathrm{AcOH}, 10 \mathrm{~mL}$ ) for an appropriate time. The corresponding thiazolidine derivatives precipitated out of hot solution during the reflux. The solvent was cooled, concentrated and filtered to afford the crude product which was crystallized from aqueous ethanol to give colourless amorphous solid.

\section{Method (B): Synthesis of thiohydantoin 12}

Stirring at room temperature an equimolar mixture $(0.01 \mathrm{~mol})$ of the thiazolidine derivatives 7 and 8 with phenyl isothiocyanate 11 in acidified methanol (10:0.1 MeOH/AcOH, $10 \mathrm{~mL}$ ) for two days. The corresponding thiohydantoin derivative 12 precipitated out of solution then the solvent was evaporated under reduced pressure, and the resulting residue crystallized from a proper solvent.

(2RS,4R)-2-(2-Hydroxyphenyl)thiazolidine-4-carboxylic acid (7a and 8a). The reaction was carried out according to general procedure (method A) using salicylaldehyde 1a as a carbonyl component and heating for 15 minutes. An isomeric mixture of 7a and 8a was obtained in a 1.5:1 ratio, respectively, $(0.22 \mathrm{~g}, 98 \%)^{38}$ (Lit., 78\% $)^{39}$; mp 160-162 ${ }^{\circ} \mathrm{C}$. IR (KBr) 3737, 3437 (broad), 3100, 2364, 1623 cm-1: MS (m/z \%): 225 (M+, 40), 180 (M-45, 13), 153 (48), 137 (53), 132 (99), 120 (37), 91 (40), 77 (100), 65 (39) and 51 (88); ${ }^{1} \mathrm{H}-\mathrm{NMR}\left(\mathrm{CDCl}_{3} / \mathrm{TFA}\right)$ for the major isomer 7a, $\delta: 7.69-6.93(\mathrm{~m}, 4 \mathrm{H}, \mathrm{Ar}-\mathrm{H}), 6.11(\mathrm{~s}, 1 \mathrm{H}, 2-\mathrm{H}), 5.1(\mathrm{dd}, 1 \mathrm{H}, J 4.1$ and 6.8, 4-H), 3.81 (dd, 1H, $J 8.4$ and 8.1, 5-Ha) and $3.67(\mathrm{dd}, 1 \mathrm{H}, J 5.7,5-\mathrm{Hb})$. The minor isomer 8a, $\delta$ : 7.69-6.93 (m, 4H, Ar-H), 6.20 (s, 1H, 2-H), 5.15 (t,1H, J 6.6, 4-H), 3.89 (d, 1H, J 7.5, 5-Ha) and 3.85 (d, 1H, J 7.5, 5-Hb).

$(\boldsymbol{R})$-Thiazolidine-4-carboxylic acid (7b). The reaction was carried out according to general procedure (method A) using formaldehyde $\mathbf{2} \mathbf{b}$ as a carbonyl component in acidified aqueous methanol (5:5:0.05 MeOH/ $\mathrm{H}_{2} \mathrm{O} / \mathrm{AcOH}, 10 \mathrm{~mL}$ ) and heating for $8 \mathrm{~h}$. Crystallization afforded $7 \mathbf{b}$ (1.12 g, 84\%) (Lit., 82\%, ${ }^{39} 98 \%{ }^{42}$ ); IR (KBr) 3046, 1585 and $1487 \mathrm{~cm}^{-1} ; \mathrm{m} / \mathrm{z}(\%) 133\left(\mathrm{M}^{+}, 47\right), 55$ (100), 57 (85), 60 (48), 69 (83), 73 (57), 87 (58) and 120 (55); ${ }^{1} \mathrm{H}-\mathrm{NMR}\left(\mathrm{CDCl}_{3} / \mathrm{TFA}\right) \delta: 4.99$ $(\mathrm{dd}, 1 \mathrm{H}, J 4.5$ and 6.6, 4-H), $4.70(\mathrm{~d}, 1 \mathrm{H}, J$ 10.7, 2-Ha), 4.52 (d,1H, $J$ 10.7, 2-Hb), 3.62 (dd, 1H, $J$ 4.5 and $12.9,5-\mathrm{Ha})$ and 3.57 (dd, $1 \mathrm{H}, J 6.6$ and $12.9,5-\mathrm{Hb})$.

(2RS,4R)-2-Phenylthiazolidine-4-carboxylic acid (7c and 8c). The reaction was carried out according to general procedure (method A) using benzaldehyde $2 \mathbf{c}$ as a carbonyl component and heating for $1 \mathrm{~h}$. An isomeric mixture of $\mathbf{7 c}$ and $\mathbf{8 c}$ was obtained in a 2:1 ratio, respectively, $(1.84 \mathrm{~g}$, 88\%) (Lit., 71\%, ${ }^{42} 89 \%{ }^{43}$ ); IR (KBr) 3421, 2963, 1480, 1137 and $857 \mathrm{~cm}^{-1} ; \mathrm{m} / z\left(\mathrm{ESI}^{+}\right) 210.0603$ $\left(100 \% \mathrm{MH}^{+}\right), 232.0 \quad\left(3 \%, \mathrm{MNa}^{+}\right)$, (Found $\mathrm{MNa}^{+} 232.040196 \mathrm{C}_{10} \mathrm{H}_{11} \mathrm{NNaO}_{2} \mathrm{~S}$ requires 232.040270); ${ }^{1} \mathrm{H}-\mathrm{NMR}\left(\mathrm{CDCl}_{3} / \mathrm{CD}_{3} \mathrm{OD}\right)$ for the major isomer $7 \mathbf{c}, \delta: 7.55-7.33(\mathrm{~m}, 5 \mathrm{H}, \mathrm{Ar}-\mathrm{H}), 5.55$ (s, 1H, 2-H), 3.99 (dd, 1H, J 7.3 and 8.6, 4-H), 3.52 (dd, 1H, J 7.3 and 10.4, 5-Ha,) and 3.20 (dd, $1 \mathrm{H}, J 8.6$ and 10.4, 5-Hb). The minor isomer 8c, $\delta: 7.55-7.33(\mathrm{~m}, 5 \mathrm{H}, \mathrm{Ar}-\mathrm{H}), 5.77(\mathrm{~s}, 1 \mathrm{H}, 2-\mathrm{H})$, 
4.27 (dd, 1H, J 5.6 and 7.5, 4-H), 3.45 (dd, 1H, J 7.5 and 10.9, 5-Ha) and 3.31 (dd, 1H, J 5.6 and $10.9,5-\mathrm{Hb})$.

$\mathrm{NOE}$ data $\left(\mathrm{CDCl}_{3} / \mathrm{CD}_{3} \mathrm{OD}\right)$ for $7 \mathbf{c}$ :

\begin{tabular}{cccccc}
\hline \multirow{2}{*}{$\begin{array}{c}\text { Irradiated } \\
\text { protons }\end{array}$} & \multicolumn{5}{c}{ \% Enhancement } \\
\cline { 2 - 6 } & $2-\mathrm{H}$ & $4-\mathrm{H}$ & $5-\mathrm{Ha}$ & $5-\mathrm{Hb}$ & $\mathrm{Ar}-\mathrm{H}$ \\
\hline $2-\mathrm{H}$ & & 3.82 & 3.72 & - & $4.53(\delta 7.51)$ \\
$4-\mathrm{H}$ & 3.08 & & 1.44 & - & - \\
\hline
\end{tabular}

$\mathrm{NOE}$ data $\left(\mathrm{CDCl}_{3} / \mathrm{CD}_{3} \mathrm{OD}\right)$ for $\mathbf{8 c}$ :

\begin{tabular}{llllll}
\hline $\begin{array}{l}\text { Irradiated } \\
\text { protons }\end{array}$ & \multicolumn{5}{c}{$\%$ Enhancement } \\
\cline { 2 - 5 } $4-\mathrm{H}$ & $4-\mathrm{H}$ & $5-\mathrm{Ha}$ & $5-\mathrm{Hb}$ & $\mathrm{Ar}-\mathrm{H}$ \\
\hline \multirow{2}{*}{$4-\mathrm{H}$} & & 5.44 & - & $5.04(\delta 7.54)$ \\
& - & & & & $2.26(\delta 7.38)$ \\
\hline
\end{tabular}

(2RS,4R)-2-(4-Hydroxyphenyl)thiazolidine-4-carboxylic acid (7d and 8d). The reaction was carried out according to general procedure (method A) using 4-hydroxybenzaldehyde $\mathbf{2 d}$ as a carbonyl component and heating for $2 \mathrm{~h}$. An isomeric mixture of $\mathbf{7 d}$ and $\mathbf{8 d}$ was obtained in a 3:1 ratio, respectively, (2 g, 89\%) (Lit., 91\%, ${ }^{39} 86 \%{ }^{42}$ ); IR (KBr) 3138, 2918, 2824, 1474, 1203 and 876; $\mathrm{cm}^{-1} ; \mathrm{m} / \mathrm{z}\left(\mathrm{ESI}^{+}\right) 226.05\left(33 \% \mathrm{MH}^{+}\right)$, (Found $\mathrm{MH}^{+} 226.053467 \mathrm{C}_{10} \mathrm{H}_{12} \mathrm{NO}_{3} \mathrm{~S}$ requires 226.053241); ${ }^{1} \mathrm{H}-\mathrm{NMR}\left(\mathrm{CDCl}_{3} / \mathrm{CD}_{3} \mathrm{OD}\right)$ for the major isomer $\mathbf{7 d}, \delta: 7.42(\mathrm{~d}, 2 \mathrm{H}, J$ 8.6, Ar-H), 6.86 $(\mathrm{d}, 2 \mathrm{H}, J$ 8.6, Ar-H), $5.50(\mathrm{~s}, 1 \mathrm{H}, 2-\mathrm{H}), 4.03(\mathrm{t}, 1 \mathrm{H}, J 7.5,4-\mathrm{H}), 3.53(\mathrm{dd}, 1 \mathrm{H}, J 7.5$ and 10.8, 5-Ha) and $3.31(\mathrm{dd}, 1 \mathrm{H}, J 7.5$ and 10.8, 5-Hb). The minor isomer $8 \mathrm{~d}, \delta: 7.41(\mathrm{~d}, 2 \mathrm{H}, J$ 8.7, Ar-H), 6.85 $(\mathrm{d}, 2 \mathrm{H}, J$ 8.7, Ar-H), $5.71(\mathrm{~s}, 1 \mathrm{H}, 2-\mathrm{H}), 4.36$ (dd, $1 \mathrm{H}, J 5.6$ and 7.4, 4-H), 3.54 (dd, $1 \mathrm{H}, J 7.4$ and $11.1,5-\mathrm{Ha})$ and $3.42(\mathrm{dd}, 1 \mathrm{H}, J 5.6$ and $11.1,5-\mathrm{Hb})$.

(2RS,4R)-2-(2-Methoxyphenyl)thiazolidine-4-carboxylic acid (7e and 8e). The reaction was carried out according to general procedure (method A) using 2-methoxy-benzaldehyde $2 \mathbf{e}$ as a carbonyl component and heating for $4 \mathrm{~h}$. An isomeric mixture of $\mathbf{7 e}$ and $\mathbf{8 e}$ was obtained in a 2:1 ratio, respectively, $\left(1.8 \mathrm{~g}, 75 \%\right.$ ) (Lit., 83\%, ${ }^{39} 65 \%{ }^{43}$ ); IR (KBr) 3420, 2960, 1459, 1269, 1190, 846 and $793 \mathrm{~cm}^{-1} ; \mathrm{m} / \mathrm{z}$ (\%) $240\left(\mathrm{MH}^{+}, 7.88\right), 55$ (19), 57 (16), 60 (10), 69 (14), 76 (17), 87 (11), 91 (100), 103 (12), 107 (20), 119 (47), 132 (27), 135 (18), 193 (16), 207 (7); ${ }^{1} \mathrm{H}-\mathrm{NMR}$ (CDCl $\mathrm{ClTFA}_{3}$ for the major isomer 7e, $\delta: 7.54-7.39(\mathrm{~m}, 4 \mathrm{H}, \mathrm{Ar}-\mathrm{H}), 6.02(\mathrm{~s}, 1 \mathrm{H}, 2-\mathrm{H}), 5.04(\mathrm{dd}, 1 \mathrm{H}, J 3.3$ and 7.9, 4-H), 3.95 (s, 3H, O-Me), 3.78 (dd, $1 \mathrm{H}, J 7.9$ and 13.0, 5-Ha) and 3.70 (dd, $1 \mathrm{H}, J 3.3$ and 13.0, $5 \mathrm{Hb})$.

(2RS,4R)-2-(4-Chlorophenyl)thiazolidine-4-carboxylic acid (7f and 8f). The reaction was carried out according to general procedure (method A) using 4-chlorobenzaldehyde $2 \mathbf{f}$ as a carbonyl component and heating for $2 \mathrm{~h}$. An isomeric mixture of $\mathbf{7 f}$ and $\mathbf{8 f}$ was obtained in a 2.5:1 ratio, respectively, (2.26 g, 93\%) (Lit., 73\%, ${ }^{39} 75 \%{ }^{43}$ ); IR (KBr) 3427, 2964, 1490, 1436, 1135 and $740 ; \mathrm{cm}^{-1} ; \mathrm{m} / \mathrm{z}\left(\mathrm{ESI}^{+}\right) 244.0\left(65 \% \mathrm{MH}^{+}\right)$, (Found $\mathrm{MH}^{+} 244.019803 \mathrm{C}_{10} \mathrm{H}_{11} \mathrm{ClNO}_{2} \mathrm{~S}$ requires 244.019354); ${ }^{1} \mathrm{H}-\mathrm{NMR}\left(\mathrm{CDCl}_{3} / \mathrm{CD}_{3} \mathrm{OD}\right)$ for the major isomer 7f, $\delta: 7.48(\mathrm{~d}, 2 \mathrm{H}, J 8.5, \mathrm{Ar}-\mathrm{H}), 7.35$ $(\mathrm{d}, 2 \mathrm{H}, J$ 8.5, Ar-H), $5.51(\mathrm{~s}, 1 \mathrm{H}, 2-\mathrm{H}), 3.98(\mathrm{dd}, 1 \mathrm{H}, J 7.3$ and 8.6, 4-H), $3.51(\mathrm{dd}, 1 \mathrm{H}, J 7.3$ and $10.5,5-\mathrm{Ha})$ and $3.19(\mathrm{dd}, 1 \mathrm{H}, J 8.6$ and $10.5,5-\mathrm{Hb})$. The minor isomer 8f, $\delta$ : $7.44(\mathrm{~d}, 2 \mathrm{H}, J 8.6$, 
Ar-H), 7.31 (d, 2H, J 8.6, Ar-H), $5.76(\mathrm{~s}, 1 \mathrm{H}, 2-\mathrm{H}), 4.19$ (dd, 1H, J 5.9 and 7.2, 4-H), 3.42 (dd, 1H, $J 7.2$ and 10.7, 5-Ha) and 3.26 (dd, $1 \mathrm{H}, J 5.9$ and 10.7, 5-Hb).

$\mathrm{NOE}$ data $\left(\mathrm{CDCl}_{3} / \mathrm{CD}_{3} \mathrm{OD}\right)$ for $7 \mathbf{f}$ :

\begin{tabular}{cccccc}
\hline Irradiated & \multicolumn{5}{c}{$\%$ Enhancement } \\
\cline { 2 - 6 } protons & $2-\mathrm{H}$ & $4-\mathrm{H}$ & $5-\mathrm{Ha}$ & $5-\mathrm{Hb}$ & $\mathrm{Ar}-\mathrm{H}$ \\
\hline $2-\mathrm{H}$ & & 2.45 & - & - & $1.91(\delta 7.48)$ \\
$4-\mathrm{H}$ & 3.65 & & 1.74 & - & $3.19(\delta 7.48)$ \\
\hline
\end{tabular}

(2RS,4R)-2-(3-Nitrophenyl)thiazolidine-4-carboxylic acid (7g and $8 \mathrm{~g})$. The reaction was carried out according to general procedure (method A) using 3-nitrobenzaldehyde $\mathbf{2 g}$ as a carbonyl component and heating for $8 \mathrm{~h}$. An isomeric mixture of $\mathbf{7 g}$ and $\mathbf{8 g}$ was obtained in a 2:1 ratio, respectively, (2.34 g, 92\%) (Lit., 80\%) $)^{39}$, IR (KBr) 3447, 1548, 1429, 1197, 808 and $697 \mathrm{~cm}^{-1} ; \mathrm{m} / \mathrm{z}$ (\%) $255\left(\mathrm{MH}^{+}, 12\right), 55$ (17), 57 (20), 63 (67), 66 (14), 68 (17), 70 (12), 79 (100), 86 (10), 181 (9) and $194(10)$; ${ }^{1} \mathrm{H}-\mathrm{NMR}\left(\mathrm{CDCl}_{3} / \mathrm{TFA}\right)$ for the major isomer $7 \mathrm{~g}, \delta: 8.59-7.69(\mathrm{~m}, 4 \mathrm{H}, \mathrm{Ar}-\mathrm{H}), 6.09$ (s, 1H, 2-H), 5.16 (brt, 1H, J 5.3, 4-H) and 3.88 (brd, 2-H, J 6.12, 5-Ha and 5-Hb). The minor isomer 8g, $\delta$ : 8,95-7.69 (m, 4H, Ar-H), $6.16(\mathrm{~s}, 1 \mathrm{H}, 2-\mathrm{H}), 5.22(\mathrm{t}, 1 \mathrm{H}, J$ 6.4, 4-H), 3.98 (dd, 1H, $J$ 6.4 and $12.6,5-\mathrm{Ha}$ ) and $3.73(\mathrm{dd}, 1 \mathrm{H}, J 6.4$ and $12.6,5-\mathrm{Hb})$.

(2R,4R)-2-(4-Nitrophenyl)thiazolidine-4-carboxylic acid (7h). The reaction was carried out according to general procedure (method $\mathrm{A}$ ) using 4-nitrobenzaldehyde $\mathbf{2 h}$ as a carbonyl component and heating for $2 \mathrm{~h}$. Compound $7 \mathrm{~h}$ was obtained as the sole diastereomer, $(2.26 \mathrm{~g}, 89 \%)$; IR (KBr) 3029, 1620, 1486, 1381, 1193, 1126, 874 and $778 \mathrm{~cm}^{-1} ; \mathrm{m} / z\left(\mathrm{ESI}^{+}\right) 255.042980\left(<10 \% \mathrm{MH}^{+}\right)$, $299.0\left(<10 \%,(\mathrm{M}+2 \mathrm{Na}-\mathrm{H})^{+}\right)$, (Found $(\mathrm{M}+2 \mathrm{Na}-\mathrm{H})^{+} 299.007241 \mathrm{C}_{10} \mathrm{H}_{9} \mathrm{~N}_{2} \mathrm{Na}_{2} \mathrm{O}_{4} \mathrm{~S}$ requires 299.007293); ${ }^{1} \mathrm{H}-\mathrm{NMR}\left(\mathrm{CDCl}_{3} / \mathrm{CD}_{3} \mathrm{OD}\right) \delta: 8.24$ (d, 2H, $J$ 8.8, Ar-H), 7.72 (d, 2H, J 8.8, Ar-H), $5.61(\mathrm{~s}, 1 \mathrm{H}, 2-\mathrm{H}), 4.03(\mathrm{dd}, 1 \mathrm{H}, J 7.23$ and 8.7, 4-H), 3.54 (dd, 1H, J 7.2 and 10.4, 5-Ha) and 3.21 $(\mathrm{dd}, 1 \mathrm{H}, J 8.7$ and $10.4,5-\mathrm{Hb})$. The minor isomer $\mathbf{8 h}\left({ }^{1} \mathrm{H}-\mathrm{NMR}\right.$ sample after $\left.24 \mathrm{~h}\right), \delta: 8.19$ (d, 2H, $J$ 8.6, Ar-H), 7.66 (d, 2H, J 8.6, Ar-H), 5.90 (s, 1H, 2-H), 4.10 (t, 1H, $J$ 6.8, 4-H), 3.42 (dd, 1H, $J$ 6.8 and $10.7,5-\mathrm{Ha})$ and $3.26(\mathrm{dd}, 1 \mathrm{H}, J 6.8$ and $10.7,5-\mathrm{Hb})$.

(3S,5R,7a $R$ )-3,5-Bis-(2-nitrophenyl)tetrahydro-1H-thiazolo[3,4-c]oxazol-1-one (9). The reaction was carried out according to general procedure (method A) using 2-nitrobenzaldehyde $\mathbf{2 i}$ as a carbonyl component and heating for 8h. Crystallization gave 9, (1.78 g, 46\%); IR (KBr), 3034, 1375, 1203, 1018, and $684 \mathrm{~cm}^{-1}, \mathrm{~m} / \mathrm{z}(\%) 387\left(\mathrm{M}^{+}, 46 \%\right), 51$ (100), 133 (45), 177 (43), 263 (52), 278 (48); m/z (ESI ${ }^{+}$) compound 9, $388.0600\left(19 \% \mathrm{MH}^{+}, \mathrm{C}_{17} \mathrm{H}_{13} \mathrm{~N}_{3} \mathrm{O}_{6} \mathrm{~S}\right), 797.0940$ (< 5\%, $\left.(2 \mathrm{M}+\mathrm{Na})^{+}\right)$, compound 7i/8i, $277.0\left(<5 \%, \mathrm{MNa}^{+}\right)$, (Found $\left(\mathrm{MNa}^{+} 277.025302 \mathrm{C}_{10} \mathrm{H}_{10} \mathrm{~N}_{2} \mathrm{NaO}_{4} \mathrm{~S}\right.$ requires 277.025349); ${ }^{1} \mathrm{H}-\mathrm{NMR}\left(\mathrm{CDCl}_{3} / \mathrm{CD}_{3} \mathrm{OD}\right) \delta: 8.16(\mathrm{dd}, 1 \mathrm{H}, J 1.3$ and 8.1, Ar-H), 8.02 (d, 1H, J 7.8, Ar-H), 7.75-7.69 (m, 2H, Ar-H), 7.65-7.56 (m, 2H, Ar-H), $7.48(\mathrm{dt}, 1 \mathrm{H}, J 1.4$ and 8.0, Ar-H), $7.38(\mathrm{dd}, 1 \mathrm{H}, J 1.1$ and 7.7, Ar-H), 7.08 (s, 1H, 3-H), 6.75 (s, 1H, 5-H), 4.21 (dd, 1H, J 0.8 and 6.5, 7a-H), 3.41 (dd, $1 \mathrm{H}, J 0.8$ and 12.5, 7-Ha) and 2.97 (dd, 1H, $J 6.5$ and 12.5, 7-Hb).

(R)-6-Phenyl-5-thioxotetrahydroimidazo[1,5-c]thiazol-7(3H)-one (12b). The reaction was carried out according to general procedure (method B) using thiazolidine $\mathbf{7 b}$. Crystallization from ethanol afforded 12b (2.38 g, 95\%) (Lit., 86\%, $\left.{ }^{49} 97 \%{ }^{50}\right)$; m.p. $158{ }^{\circ} \mathrm{C}$. IR (KBr) 2996, 1758, 1621, 1490, 1460, 1219, 874 and 764, $\mathrm{cm}^{-1} ; \mathrm{m} / \mathrm{z}(\%) 250\left(\mathrm{MH}^{+}\right.$251, 10), 55 (55), 59 (54), 77 (100), 86 
(60), 119 (12), 135 (50), and 204 (4); ${ }^{1} \mathrm{H}-\mathrm{NMR}\left(\mathrm{CDCl}_{3}\right) \delta$ : 7.53-7.28 (m, $\left.5 \mathrm{H}, \mathrm{Ph}-\mathrm{H}\right), 5.39$ (d, 1H, $J$ 9.7, 3-Ha), $4.86(\mathrm{t}, 1 \mathrm{H}, J$ 8.2, 7a-H), $4.58(\mathrm{~d}, 1 \mathrm{H}, J$ 9.7, 3-Hb), $3.44(\mathrm{dd}, 1 \mathrm{H}, J 8.2$ and 11.1, 1$\mathrm{Ha})$ and $3.23(\mathrm{dd}, 1 \mathrm{H}, J 8.2$ and $11.1,1-\mathrm{Hb})$.

$(3 S, 7 a R)-3,6-D i p h e n y l-5-t h i o x o t e t r a h y d r o i m i d a z o[1,5-c]$ thiazol-7(3H)-one $\quad(12 c) . \quad$ The reaction was carried out according to general procedure (method B) using thiazolidines 7c and 8c. Crystallization from ethanol afforded 12c (3.16 g, 97\%); m.p. $180{ }^{\circ} \mathrm{C}$. IR (KBr) 3023, 1620, 1489 , 873, 778 and $674 \mathrm{~cm}^{-1} ; \mathrm{m} / z\left(\mathrm{ESI}^{+}\right) 327.1\left(100 \% \mathrm{MH}^{+}\right)$, (Found $\mathrm{MH}^{+} 327.062930 \mathrm{C}_{17} \mathrm{H}_{15} \mathrm{~N}_{2} \mathrm{OS}_{2}$ requires 327.062032); ${ }^{1} \mathrm{H}-\mathrm{NMR}\left(\mathrm{CDCl}_{3}\right) \delta$ : 7.59-7.30 (m, $\left.10 \mathrm{H}, \mathrm{Ar}-\mathrm{H}\right), 6.81$ (s, 1H, 3-H), 4.89 (dd, $1 \mathrm{H}, J 7.1$ and 9.2, 7a-H), $3.50(\mathrm{dd}, 1 \mathrm{H}, J 7.1$ and $11.1,1-\mathrm{Ha})$ and $3.30(\mathrm{dd}, 1 \mathrm{H}, J 9.2$ and $11.1,1-$ $\mathrm{Hb}) ;{ }^{13} \mathrm{C}-\mathrm{NMR}\left(\mathrm{CDCl}_{3}\right), \delta \mathrm{c}: 184.7,170.4,138.6,132.9,129.4,129.3,128.9,128.8,128.1,126.9$, 67.0, 67.7 and 32.5.

$\mathrm{NOE}$ data $\left(\mathrm{CDCl}_{3}\right)$ for $12 \mathrm{c}$ :

\begin{tabular}{llllll}
\hline \multirow{2}{*}{$\begin{array}{l}\text { Irradiated } \\
\text { protons }\end{array}$} & \multicolumn{5}{c}{$\%$ Enhancement } \\
\cline { 2 - 6 } $3-\mathrm{H}$ & $7 \mathrm{a}-\mathrm{H}$ & $1-\mathrm{Ha}$ & $1-\mathrm{Hb}$ & $\mathrm{Ar}-\mathrm{H}$ \\
\hline $3-\mathrm{H}$ & & 0.48 & - & 0.69 & $3.83(\delta 7.57)$ \\
$7 \mathrm{a}-\mathrm{H}$ & 0.54 & & 5.50 & - & $2.82(\delta 7.57)$ \\
$1-\mathrm{Ha}$ & - & 8.38 & & 26.67 & - \\
$1-\mathrm{Hb}$ & 1.51 & 0.83 & 23.92 & & - \\
\hline
\end{tabular}

(3S,7aR)-3-(4-Hydroxyphenyl)-6-phenyl-5-thioxotetrahydroimidazo[1,5-c]thiazol-7(3H)one (12d). The reaction was carried out according to general procedure (method B) using thiazolidines 7d and 8d. Crystallization from ethanol afforded $\mathbf{1 2 d}(3.35 \mathrm{~g}, 98 \%)$; m.p. $178{ }^{\circ} \mathrm{C}$; IR (KBr) 3047, 2882, 1621, 1589, 1488, 855, 731 and $693 \mathrm{~cm}^{-1} ; \mathrm{m} / \mathrm{z}(\%) 342\left(\mathrm{MH}^{+}, 64\right), 55$ (100), 57 (96), 77 (49), 106 (52), 135 (59), 192 (47), 205 (50), 248 (49), 299 (52), 311 (56) and 326 (60); ${ }^{1} \mathrm{H}-\mathrm{NMR}\left(\mathrm{CDCl}_{3}\right), \delta: 7.54-7.30(\mathrm{~m}, 9 \mathrm{H}, \mathrm{Ar}-\mathrm{H}), 6.74(\mathrm{~s}, 1 \mathrm{H}, 3-\mathrm{H}), 4.85(\mathrm{dd}, 1 \mathrm{H}, J 7.1$ and 9.2, 7a$\mathrm{H}), 3.48(\mathrm{dd}, 1 \mathrm{H}, J 7.1$ and $11.1,1-\mathrm{Ha})$ and $3.30(\mathrm{dd}, 1 \mathrm{H}, J 9.2$ and $11.1,1-\mathrm{Hb}) .{ }^{13} \mathrm{C}-\mathrm{NMR}\left(\mathrm{CDCl}_{3}\right)$ $\delta \mathrm{c}: 184.7,170.2,137.0,134.7,132.7,129.5,129.3,129.0,128.4,128.0,66.7,66.5$ and 32.5 . (3S,7aR)-3-(2-Methoxyphenyl)-6-phenyl-5-thioxotetrahydroimidazo[1,5-c]thiazol-7-one (12e). The reaction was carried out according to general procedure (method B) using thiazolidine 7e and 8e. Crystallization from chloroform afforded 12e (3.24 g, 91\%); m.p. $178{ }^{\circ} \mathrm{C}$; IR (KBr) 3001, 1487, 1294, 873and $846 \mathrm{~cm}^{-1} ; \mathrm{m} / \mathrm{z}(\%) 356 \mathrm{C}_{18} \mathrm{H}_{16} \mathrm{~N}_{2} \mathrm{O}_{2} \mathrm{~S}_{2},\left(\mathrm{MH}^{+}, 32\right), 91$ (100), 101 (37), 135 (39), 278 (63), 282 (41), 298 (41) and 327 (34); ${ }^{1} \mathrm{H}-\mathrm{NMR}\left(\mathrm{CDCl}_{3}\right), \delta$ : 7.56-7.50 (m, 3H, ArH), 7.39-7.30 (m, 4H , Ar-H), 7.04 (d, 1H, J 7.6, Ar-H), 6.98 (d, 1H, J 8.3, Ar-H), 6.85 (s, 1H, 3H), $5.20(\mathrm{dd}, 1 \mathrm{H}, J 6.9$ and 10.2, 7a-H), $3.46(\mathrm{dd}, 1 \mathrm{H}, J 6.9$ and 11.1, 1-Ha) and 3.30 (dd, $1, J 10.2$ and $11.1 \mathrm{H}, 1-\mathrm{Hb})$.

(3S,7aR)-3-(4-Chlorophenyl)-6-phenyl-5-thioxotetrahy droimidazo[1,5-c]thiazol-7(3H)-one (12f). The reaction was carried out according to the general procedure (method B) using thiazolidines $\mathbf{7 f}$ and $\mathbf{8 f}$ and stirring for $48 \mathrm{~h}$. Crystallization from chloroform afforded $\mathbf{1 2 f}$ (3.55 g, 98.5\%); m.p. $194-196{ }^{\circ} \mathrm{C}$; IR (KBr) 1620, 1490, 1338, 872, 778 and 515; $\mathrm{cm}^{-1}$; m/z (\%) 342 $\mathrm{C}_{17} \mathrm{H}_{13} \mathrm{ClN}_{2} \mathrm{OS}_{2}, 77$ (100), 86 (17), 116 (40), 135 (40), 205 (19), 116 (12), 295 (14), and 248 (10); ${ }^{1} \mathrm{H}-\mathrm{NMR}\left(\mathrm{CDCl}_{3}\right), \delta: 7.54-7.30(\mathrm{~m}, 9 \mathrm{H}, \mathrm{Ar}-\mathrm{H}), 6.74(\mathrm{~s}, 1 \mathrm{H}, 3-\mathrm{H}), 4.89$ (dd, 1H, J 7.0 and 9.3, 7a- 
$\mathrm{H}), 3.50(\mathrm{dd}, 1 \mathrm{H}, J 7.0$ and $11.1,1-\mathrm{Ha})$ and $3.31(\mathrm{dd}, 1 \mathrm{H}, J 9.3$ and $11.1,1-\mathrm{Hb}) ;{ }^{13} \mathrm{C}-\mathrm{NMR}\left(\mathrm{CDCl}_{3}\right)$ $\delta: 184.6,170.4,137.0,134.7,132.7,129.5,129.3,129.0,128.4,128.0,66.8,66.4$ and 32.4. $\mathrm{NOE}$ data $\left(\mathrm{CDCl}_{3}\right)$ for $\mathbf{1 2 f}$ :

\begin{tabular}{llllll}
\hline \multirow{2}{*}{$\begin{array}{l}\text { Irradiated } \\
\text { protons }\end{array}$} & \multicolumn{5}{c}{$\%$ Enhancement } \\
\cline { 2 - 6 } & $3-\mathrm{H}$ & $7 \mathrm{a}-\mathrm{H}$ & $1-\mathrm{Ha}$ & $1-\mathrm{Hb}$ & $\mathrm{Ar}-\mathrm{H}$ \\
\hline $3-\mathrm{H}$ & & 0.50 & - & 0.87 & $4.98(\delta 7.53)$ \\
$7 \mathrm{a}-\mathrm{H}$ & 0.42 & & 5.99 & - & $2.65(\delta 7.53)$ \\
$1-\mathrm{Ha}$ & - & 11.01 & & 31.52 & - \\
$1-\mathrm{Hb}$ & 1.61 & 1.58 & 25.29 & & - \\
\hline
\end{tabular}

(3S,7aR)-3-(3-Nitrophenyl)-6-phenyl-5-thioxotetrahydroimidazo[1,5-c]thiazol-7(3H)-one (12g). The reaction was carried out according to the general procedure (method B) using thiazolidines 7g and 8g. Crystallization from ethanol afforded 12g (3.57 g, 96.5\%); m.p. 200-202 ${ }^{\circ} \mathrm{C}$; IR (KBr) 3056, 1620, 1489, 1342, 846 and $727 \mathrm{~cm}^{-1}$; m/z (\%) $371 \mathrm{C}_{17} \mathrm{H}_{13} \mathrm{~N}_{3} \mathrm{O}_{3} \mathrm{~S}_{2}, 77$ (100), 118 (10), 135 (35), 175 (23), 219 (12), 347 (15), 293 (12), and 324 (9); ${ }^{1} \mathrm{H}-\mathrm{NMR}\left(\mathrm{CDCl}_{3} / \mathrm{TFA}\right), \delta$ : $8.48(\mathrm{~s}, 1 \mathrm{H}, \mathrm{Ar}-\mathrm{H}), 8.27(\mathrm{td}, 1 \mathrm{H}, J 1.2$ and 8.1, Ar-H), $7.96(\mathrm{dd}, 1 \mathrm{H}, J 0.6$ and 8.1, Ar-H), 7.65 (t, $1 \mathrm{H}, J$ 8.1, Ar-H), 7.56-7.52 (m, 3H, Ph-H), 7.93-7.27 (m, 2H, Ph-H), 6.80 (s, 1H, 3-H), 5.10 (dd, $1 \mathrm{H}, J 7.1$ and 9.6, 7a-H), $3.58(\mathrm{dd}, 1 \mathrm{H}, J 7.1$ and 11.0, 1-Ha) and 3.41 (dd, 1H, $J 9.6$ and 11.0, 1$\mathrm{Hb})$.

(3S,7aR)-3-(4-Nitrophenyl)-6-phenyl-5-thioxotetrahydroimidazo[1,5-c]thiazol-7(3H)-one (12h). The reaction was carried out according to general procedure (method B) using thiazolidines 7h. Crystallization from chloroform afforded 12h (3.33 g, 94\%); m.p. 160-162 ${ }^{\circ} \mathrm{C}$; IR (KBr) 3022, 1440, 874, 753 and $629 \mathrm{~cm}^{-1} ; \mathrm{m} / \mathrm{z}\left(\mathrm{ESI}^{+}\right) 372.0\left(14 \% \mathrm{MH}^{+}\right)$, (Found $\mathrm{MH}^{+} 372.046864$ $\mathrm{C}_{17} \mathrm{H}_{14} \mathrm{~N}_{3} \mathrm{O}_{3} \mathrm{~S}_{2}$ requires 372.047110); ${ }^{1} \mathrm{H}-\mathrm{NMR}\left(\mathrm{CDCl}_{3}\right), \delta: 8.28(\mathrm{~d}, 2 \mathrm{H}, J$ 8.7, $\mathrm{Ar}-\mathrm{H}), 7.74(\mathrm{~d}, 2 \mathrm{H}$, $J$ 8.7, Ar-H), 7.57-7.32 (m, 5H, Ph-H), 6.83 (s, 1H, 3-H), 4.92 (dd, 1H, J 7.0 and 9.4, 7a-H), 3.53 (dd, 1H, J 7.0 and 11.2, 1-Ha) and 3.36 (dd, 1H, $J 9.4$ and 11.2, 1-Hb).

(3S,7aR)-3-(2-Nitrophenyl)-6-phenyl-5-thioxotetrahydroimidazo[1,5-c]thiazol-7(3H)-one (12i). The reaction was carried out according to general procedure (method B) using 3,5-bis-(2nitrophenyl)dihydrothiazolo[3,4-c] oxazol-1-one 9. Crystallization from ethanol afforded 12i (3.51 g, $95 \%$ ); m.p. $230-232{ }^{\circ} \mathrm{C}$; IR (KBr) 2887, 1497, 1345, 853, 786 and $689 \mathrm{~cm}^{-1} ; \mathrm{m} / \mathrm{z}(\%) 371,55$ (41), 63 (100), 135 (34), 208 (22), 112 (49), 237 (24), 325 (17), and 355 (18); ${ }^{1} \mathrm{H}-\mathrm{NMR}$ $\left(\mathrm{CDCl}_{3} / \mathrm{CD}_{3} \mathrm{OD}\right) \delta: 8.17(\mathrm{dd}, 1 \mathrm{H}, J 1.2$ and 8.2, $\mathrm{Ar}-\mathrm{H}), 7.74(\mathrm{dt}, 1 \mathrm{H}, J 1.3$ and 8.2, Ar-H), 7.67 (dd, $1 \mathrm{H}, J 1.5$ and 7.9, Ar-H), 7.59-7.48 (m, 4H, Ar-H), 7.37-7.33 (m, 2H, Ar-H), 7.35 (s, 1H, 3H), $5.08(\mathrm{dd}, 1 \mathrm{H}, J 7.4$ and 9.3, 7a-H), $3.43(\mathrm{dd}, 1 \mathrm{H}, J 7.4$ and 11.0, 1-Ha) and $3.36(\mathrm{dd}, 1 \mathrm{H}, J 9.3$ and $11.0,1-\mathrm{Hb})$.

\section{Acknowledgements}

We acknowledge support from South Valley University. M. F. A and E. E. E. thank Leeds University and Prof Ronald Grigg for undertaking spectroscopic analysis in their labs. 


\section{Supplementary data}

The supplementary file is a pdf document showing the relevant HRMS traces that are reported in this paper.

\section{References}

1. Page, M. I. The Chemistry of $\beta$-Lactams; Springer Science + Business Media Dordrecht, 1992.

2. Hamada, Y.; Kiso, Y. Expert Opin. Drug Discov. 2012, 7, 903-922. https://doi.org/10.1517/17460441.2012.712513

3. Zhang, B.; Gong, J.; Yang, Y.; Dong, S. J. Pept. Sci. 2011, 17, 601-603. https://doi.org/10.1002/psc.1396

4. Magdaleno, A.; Ahn, I-Y.; Paes, L. S.; Silber, A. M. PLoS ONE 2009, 4, e4534. https://doi.org/10.1371/journal.pone.0004534

5. Postma, T. M.; Albericio, F. Org. Lett. 2014, 16, 1772-1775. https://doi.org/10.1021/o15004725

6. Wöhr, T.; Wahl, F.; Nefzi, A.; Rohwedder, B.; Sato, T.; Sun, X.; Mutter, M. J. Am. Chem. Soc. 1996, 118, 9218-9227. https://doi.org/10.1021/ja961509q

7. Tam, J. P.; Miao, Z. J. Am. Chem. Soc. 1999, 121, 9013-9022. https://doi.org/10.1021/ja991153t

8. Zhang, Q.; Zhou, H.; Zhai, S.; Yan, B. Curr. Pharm. Des. 2010, 16, 1826-1842. https://doi.org/10.2174/138161210791208983

9. Zobel, K.; Wang, L.; Varfolomeev, E.; Franklin, M. C.; Elliott, L. O.; Wallweber, H. J. A.; Okawa, D. C.; Flygare, J. A.; Vucic, D.; Fairbrother W. J.; Deshayes, K. ACS Chem. Biol. 2006, 1, 525-534. https://doi.org/10.1021/cb600276q

10. Bertamino, A.; Soprano, M.; Musella, S.; Rusciano, M. R.; Sala, M.; Vernieri, E.; Di Sarno, V.; Limatola, A.; Carotenuto, A.; Cosconati, S.; Grieco, P.; Novellino, E.; Illario, M.; Campiglia, P.; Gomez-Monterrey, I. J. Med. Chem. 2013, 56, 5407-5421, and references cited therein.

\section{https://doi.org/10.1021/jm400311n}

11. Gomez-Monterrey, I.; Bertamino, A.; Porta, A.; Carotenuto, A.; Musella, S.; Aquino, C.; Granata, I.; Sala, M.; Brancaccio, D.; Picone, D.; Ercole, C.; Stiuso, P.; Campiglia, P.; Grieco, P.; Ianelli, P.; Maresca, B.; Novellino, E. J. Med. Chem. 2010, 53, 8319-8329. https://doi.org/10.1021/jm100838z

12. Önen-Bayram, F. E.; Buran, K.; Durmaz, I.; Berk, B.; Cetin-Atalay, R. Med. Chem. Commun. 2015, 6, 90-93. https://doi.org/10.1039/C4MD00306C 
13. Önen-Bayram, F. E.; Durmaz, I.; Scherman, D.; Herscovici, J.; Cetin-Atalay, R. Bioorg. Med. Chem. 2012, 20, 5094-5102.

https://doi.org/10.1016/j.bmc.2012.07.016

14. Serra, A. C.; Gonsalves, A. M. d'A . R.; Laranjo, M.; Abrantes, A. M.; Gonçalves, A. C.; Sarmento-Ribeiro, A. B.; Botelho, M. F. Eur. J. Med. Chem. 2012, 53, 398-402.

https://doi.org/10.1016/j.ejmech.2012.04.003

15. Santos, K.; Laranjo, M.; Abrantes, A. M.; Brito, A. F.; Gonçalves, C.; Ribeiro, A. B. S.;

Botelho, M. F.; Soares, M. I. L.; Oliveira, A. S. R.; Pinho e Melo, T. M. V. D. Eur. J. Med. Chem. 2014, 79, 273-281 and references cited therein.

https://doi.org/10.1016/j.ejmech.2014.04.008

16. Thalamuthu, S.; Annaraj, B.; Vasudevan, S.; Sengupta, S.; Neelakantan, M. A. J. Coord. Chem. 2013, 66, 1805-1820. https://doi.org/10.1080/00958972.2013.791393

17. Lu, Y.; Wang, Z.; Li, C. -M.; Chen, J.; Dalton, J. T.; Li W.; Miller, D. D. Bioorg. Med. Chem. 2010, 18, 477-495 and references cited therein.

https://doi.org/10.1016/j.bmc.2009.12.020

18. Miura, T.; Hidaka, K.; Uemura, T.; Kashimoto, K.; Hori, Y.; Kawasaki, Y.; Ruben, A. J.;

Freire, E.; Kimura, T.; Kiso, Y. Bioorg. Med. Chem. Lett. 2010, 20, 4836-4839.

https://doi.org/10.1016/j.bmcl.2010.06.099

19. Solomon, V. R.; Haq, W.; Srivastava, K.; Puri, S. K.; Katti, S. B. J. Enz. Inhib. Med. Chem. 2013, 28, 619-626.

https://doi.org/10.3109/14756366.2012.666537

20. Iwamoto, T.; Inoue, Y.; Ito, K.; Sakaue, T.; Kita, S.; Katsuragi, T. Mol. Pharm. 2004, 66, 4555.

https://doi.org/10.1124/mol.66.1.45

21. Artali, R.; Bombieri, G.; Meneghetti, F.; Nava, D.; Ragg, E.; Stradi, R. Il Farmaco 2003, 58, 883-889.

https://doi.org/10.1016/S0014-827X(03)00146-0

22. Chung, K. W.; Jeong, H. O.; Jang, E. J.; Choi, Y. J.; Kim, D. H.; Kim, S. R.; Lee, K. J.; Lee, H. J.; Chun, P.; Byun, Y.; Moon, H. R.; Chung, H. Y. Biochim. Biophys. Acta 2013, 1830, 4752-4761 and references cited therein.

23. Frimayanti, N.; Lee, V. S.; Zain, S. M.; Wahab, H. A.; Rahman, N. A. Med. Chem. Res. 2014, 23, 1447-1453 and references cited therein.

https://doi.org/10.1007/s00044-013-0750-X

24. Nagasree, K. P.; Kumar, M. M. K.; Prasad, Y. R.; Sriram, D.; Yogeeswari, P. Curr. ComputerAided Drug Des. 2014, 10, 274-281. https://doi.org/10.2174/1573409910666141121100515

25. Ghosh, A. K.; Gemma, S.; Simoni, E.; Baldridge, A.; Walters, D. E.; Ide, K.; Tojo, Y.; Koh, Y.; Amano, M.; Mitsuya, H. Bioorg. Med. Chem. Lett. 2010, 20, 1241-1246.

https://doi.org/10.1016/j.bmcl.2009.11.123 
26. Ershov, A. Y.; Nasledov, D. G.; Lagoda, I. V.; Shamanin, V. V. Chem. Heterocyclic Comp. 2014, 50, 1032-1038. https://doi.org/10.1007/s10593-014-1560-X

27. Confalone, P. N.; Pizzolato, G.; Baggiolini, E. G.; Lollar, D.; Uskokovii, M. R. J. Am. Chem. Soc. 1977, 99,7020-7026. https://doi.org/10.1021/ja00463a042

28. Seki, M.; Hatsuda, M.; Mori, Y.; Yoshida, S.; Yamada, S.; Shimizu, T. Chem. Eur. J. 2004, $10,6102-6110$. https://doi.org/10.1002/chem.200400733

29. Pirovani, R. V.; Brito, G. A.; Barcelos, R. C.; Pilli, R. A. Mar. Drugs 2015, 13, 3309-3324. https://doi.org/10.3390/md13063309

30. Takeuchi, R.; Shimokawa, J.; Fukuyama, T. Chem. Sci. 2014, 5, 2003-2006. https://doi.org/10.1039/c3sc53222d

31. Segade, Y.; Montaos, M. A., Rodríguez, J.; Jiménez, C. Org. Lett. 2014, 16, 5820-5823.

32. Ciuffreda, P.; Casati, S.; Meroni, G.; Santaniello, E. Tetrahedron 2013, 69, 5893-5897. https://doi.org/10.1016/j.tet.2013.05.019

33. Cacciatore, I.; Cornacchia, C.; Pinnen, F.; Mollica, A.; Stefano, A. D. Molecules 2010, 15, 1242-1264. https://doi.org/10.3390/molecules15031242

34. Bjelton, L.; Fransson, G. -B. JPEN 1990, 14, 177-182. https://doi.org/10.1177/0148607190014002177

35. Wtodek, L.; Grabowska, A.; Marcinkiewicz, J. Immunopharmacology 1995, 30, 51-58 and references cited therein. https://doi.org/10.1016/0162-3109(95)00004-D

36. Poirel, A.; De Nicola, A.; Ziessel, R.; J. Org. Chem. 2014, 79, 11463-11472 and references cited therein. https://doi.org/10.1021/jo502068u

37. Kim, H. -J.; Shin, H. -S. Anal. Chim. Acta 2011, 702, 225-232. https://doi.org/10.1016/j.aca.2011.07.006

38. Aly, M. F.; Abbas-Temirek, H. H.; Elboray, E. E. Arkivoc 2010, (iii), 237-263.

39. Jagtap, R. M.; Rizvi, M. A.; Dangat, Y. B.; Pardeshi, S.; K. J. Sulfur Chem. 2016, 37, 401425. https://doi.org/10.1080/17415993.2016.1156116

40. Royer, J.; Bonin, M.; Micouin, L. Chem. Rev. 2004, 104, 2311-2352. https://doi.org/10.1021/cr020083x

41. Szilágyi, L.; Györgydeák, Z. J. Am. Chem. Soc. 1979, 101, 427-432. https://doi.org/10.1021/ja00496a026

42. Khan, K. M.; Ullah, Z.; Lodhi, M. A.; Ali, M.; Choudhary, M. I.; ur-Rahman, A.; ul-Haq, Z. Molec. Divers. 2006, 10, 223-231. https://doi.org/10.1007/s11030-005-9000-6 
43. Önen Bayram, F. E.; Sipahi, H.; Acar, E. T.; Ulugöl, R. K.; Kerem, B.; Akgün, H. Eur. J. Med. Chem. 2016, 114, 337-344. https://doi.org/10.1016/j.ejmech.2016.03.019

44. Butvin, P.; Al-Ja'afareh, J.; Světlík, J.; Havránek, E. Chem. Papers 1999, 53, 315-322.

45. Nagasawa, H. T.; Goon, D. J. W.; Shirota, F. N. J. Heterocyclic Chem. 1981, 18, 1047-1051. https://doi.org/10.1002/jhet.5570180538

46. Vengurlekar, S.; Sharma, R.; Trivedi, P. Letters in Drug Design \& Discovery 2012, 9, 549555.

https://doi.org/10.2174/157018012800389322

47. Wang, Z. D.; Sheikh, S. O.; Zhang, Y. Molecules 2006, 11, 739-750.

https://doi.org/10.3390/11100739

48. Campiglia, P.; Scrima, M.; Grimaldi, M.; Cioffi, G.; Bertamino, A.; Sala, M.; Aquino, C.; Gomez-Monterrey, I.; Grieco, P.; Novellino, E.; D’Ursi, A. M. Chem. Biol. Drug Des. 2009, 74, 224-233. https://doi.org/10.1111/j.1747-0285.2009.00853.x

49. Lalezari, I.; Seifter, S.; Thein, A. J. Heterocyclic Chem. 1983, 20, 483-485. https://doi.org/10.1002/jhet.5570200247

50. Vavsari, V. F.; Ziarani, G. M.; Balalaie, S.; Latifi, A.; Karimi, M.; Badiei, A. Tetrahedron 2016, 72, 5420-5426. https://doi.org/10.1016/j.tet.2016.07.034

51. Song, Z. -C.; Ma, G. -Y.; Zhu, H. -L. RSC Adv. 2015, 5, 24824-24833. https://doi.org/10.1039/C4RA15284K

52. Györgydeák, Z.; Kövér, K. E.; Miskolczi, I.; Zékány, A.; Rantal, F.; Luger, R.; Strumpel, M. K. J. Heterocyclic chem. 1996, 33, 1099-1105.

https://doi.org/10.1002/jhet.5570330417 